\title{
BLOOD COUNTS OF NEWBORN INFANTS IN RELATION TO ICTERUS NEONATORUM
}

\author{
BY \\ L. C. Martin, M.A., M.B., B.Chir.(Cаntab.), \\ Late House Physician, Addenbrooke's Hospital, Cambridge, \\ AND
}

S. M. EVANS, B.A., B.Chir.(Cantab.),

Late Obstetric House Surgeon, Addenbrooke's Hospital, Cambridge.

This investigation into the blood picture of newborn infants was made primarily to determine if any relationship existed between the erythrocyte count and the occurrence of icterus neonatorum. At the same time, independent information was obtained on the average blood count of newborn infants and the erythrocyte counts and haemoglobin estimations of infants born by caesarean section and natural means were compared. Literature on blood counts in the newborn extends over the last forty years, during which period the use of different methods of investigation detracts considerably from the value of older findings, obtained when apparatus was relatively crude and when haematology was less exact than it is to-day. Information on the subject of icterus neonatorum is more satisfactory; the fundamental cause has recently been postulated and experimentally confirmed in animals, but the fact that it occurs in some infants, and not in others, is still not explained.

Icterus neonatorum is relatively common in newborn infants, the incidence according to various authorities varying between 30 per cent. and 80 per cent. It is said to be more frequent in small and premature infants and among the poorer classes. Jaundice usually appears on the second day after birth, and may persist as long as two or three weeks. Infants do not appear adversely affected by the jaundice, which is the only clinical finding.

\section{Previous work.}

The most recent and attractive theory of causation of icterus neonatorum has been put forward by Goldbloom and Gottlieb, who produced confirmatory experimental evidence in animals.

They argued $^{4}$ that the mixture of arterial and venous blood circulating in the human foetus was comparable to the blood of a human adult living in a state of diminished oxygen tension which had produced a polycythaemia. With the birth of the infant and cessation of diminished oxygen tension, the necessity for polycythaemia ended, a compensatory haemolysis of 
redundant red blood cells occurred and icterus neonatorum ensued. In support of this theory the same investigators ${ }^{5}$ kept guinea pigs under reduced oxygen tension, and were able to produce a polycythaemia with appearance of reticulated red cells in the circulation. On restoring the oxygen tension to normal the animals' erythrocyte counts returned to normal, but the icteric index of the serum was raised, and the van den Bergh reaction showed an indirect positive result. Thus conditions similar to icterus neonatorum were produced. The same workers later demonstrated ${ }^{6}$ that while maternal blood showed normal oxygen saturation and capacity values, foetal arterial blood possessed a decreased oxygen saturation due to deficient respiratory function in utero. Barcroft ${ }^{2}$, in a study of foetal respiration, mentioned that the blood was red in icterus neonatorum, partly from excess haemoglobin 'engendered by oxygen want' and partly from the foetal type of haemoglobin ' which acquires oxygen with ease, though it sheds it with difficulty.' Barcroft also stated that towards the end of foetal life much haemoglobin was broken down and the iron stored in the liver, to be used again postnatally. Andrewes ${ }^{1}$, who studied the van den Bergh test in jaundice, found ' almost invariably a latent jaundice at birth,' as indicated by the icteric index of the serum, explainable by the breakdown of haemoglobin before birth mentioned above. In thirty-eight cases he found, however, only a rough correspondence between the degree of bilirubinaemia at birth and subsequent occurrence of icterus neonatorum. Cases with a high bilirubinaemia commonly developed jaundice, and cases with a low reading usually did not, ' yet it was impossible to foretell with certainty-from the amount of pigment-whether jaundice would appear or not.' Hirsch and Yllpo $^{7,8}$ showed that the bilirubin content of the serum rose to a variable height during the first few days of life and then fell. They found that the peak, reached after a few days, determined the occurrence of icterus neonatorum, rather than the initial height at birth.

Bearing in mind these findings, and assuming that the source of bilirubin must be haemolysed erythrocytes, we followed the erythrocyte count of infants from birth for the first five days.

\section{Material and methods.}

Twenty infants, born at full term according to the menstrual and clinical evidence of the mothers, were investigated. Of these, ten were born by caesarean section and ten by natural means.

Method used for cell counts.-Blood was obtained approximately one to two hours after delivery, when the infants had beer bathed and their peripheral circulation established, thus avoiding misleading results from stagnation of blood in the extremities. Blood was obtained from the heel by a stab with a triangular needle deep enough to ensure a steady flow without any squeezing or pressure.

RED CELL AND WHITE CELL counts were made separately in a counting chamber having the improved Neubaer ruling, an average of two consecutive counts being made in each case.

Differential white cell counts were made on films stained by Leishman's stain, 200 cells being counted.

Haemoglobin estimations were made by Haldane's method.

After birth red cell counts were made as far as possible at twenty-four hourly intervals. 


\section{Results.}

Of the series of twenty infants, nine developed icterus neonatorum, a percentage of 45. Seven infants developed jaundice on the second day, and two on the first day after birth. No co-relation between the birth weight and development of icterus was found.

(1) At birth, average erythrocyte counts and haemoglobin estimations for infants developing icterus neonatorum, and for those who did not, were as follows:-

\begin{tabular}{|c|c|c|c|c|}
\hline \multirow[b]{2}{*}{ ICTERIC } & \multicolumn{3}{|c|}{ RED CELLS PER C.MM. (MILLIONS). } & \multirow{2}{*}{$\begin{array}{c}\text { HAEMOGLOBIN. } \\
\text { PER CENT. } \\
119\end{array}$} \\
\hline & $\begin{array}{c}\text { Average. } \\
5.528\end{array}$ & $\underset{6.080}{\text { MAXIMUM. }_{\text {A }}}$ & $\begin{array}{c}\text { Minimum. } \\
\mathbf{4 \cdot 7 8}\end{array}$ & \\
\hline NON-ICTERIC & $5 \cdot 499$ & 6.875 & $4 \cdot 67$ & 117 \\
\hline
\end{tabular}

These values are so close as to be within limits of technical error: hence it is concluded that no difference exists at birth in the erythrocyte count or haemoglobin value of the two classes. It is noteworthy that the maximum and minimum values in the two classes are comparable.

(2) Subsequent daily erythrocyte counts showed that infants developing icterus neonatorum had a higher average count than either the total average, or the average of those without icterus (see chart I). Similarly

CHART I.

Curves Showing average of DaILY eRythrocyte counts IN FIRST FIVE DAYS OF LIFE.

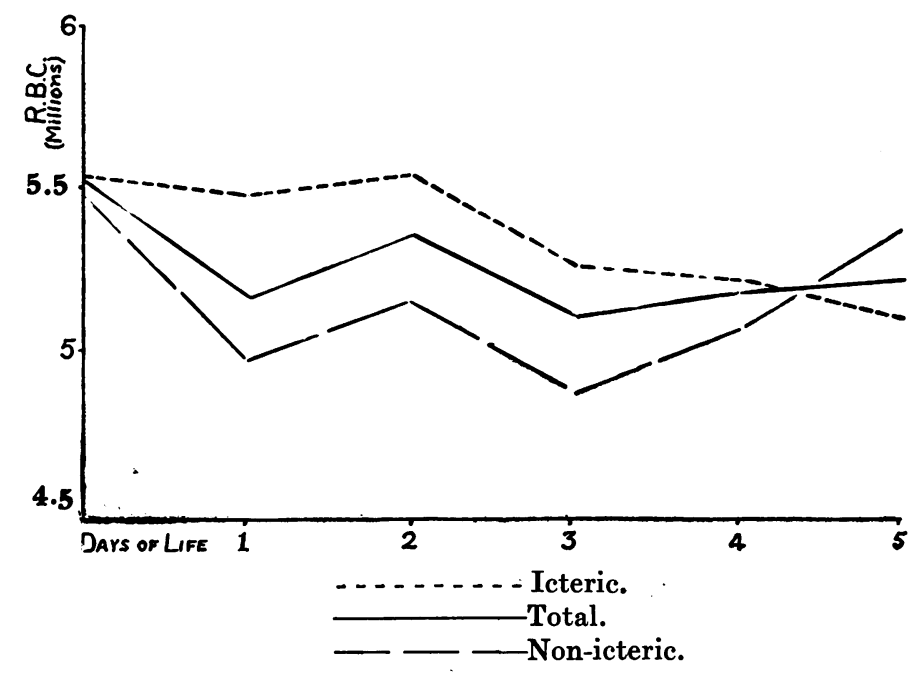

the non-icteric curve was lower than either the total average or icteric curves. All curves showed a downward tendency, and it is noteworthy that on the fifth day the average counts in both classes were within 250,000.

In individual daily curves a peak was reached on the second or third day in some infants developing icterus, followed by a fall. This fall in the erythrocyte count presumably corresponds to the rise in serum bilirubin described by Hirsch and Yllpo. However, the fact must be emphasized 
that, given a curve of erythrocyte values in the first five days of life, it is impossible to deduce from it whether the infant had developed icterus neonatorum or not, as shown by the chart of individual values (see chart II).

\section{CHART II.}

SPECIMEN CURVES OF INDIVIDUAL INFANTS SHOWING ERYTHROCYTE COUNTS DURING FIRST FIVE DAYS OF LIFE.

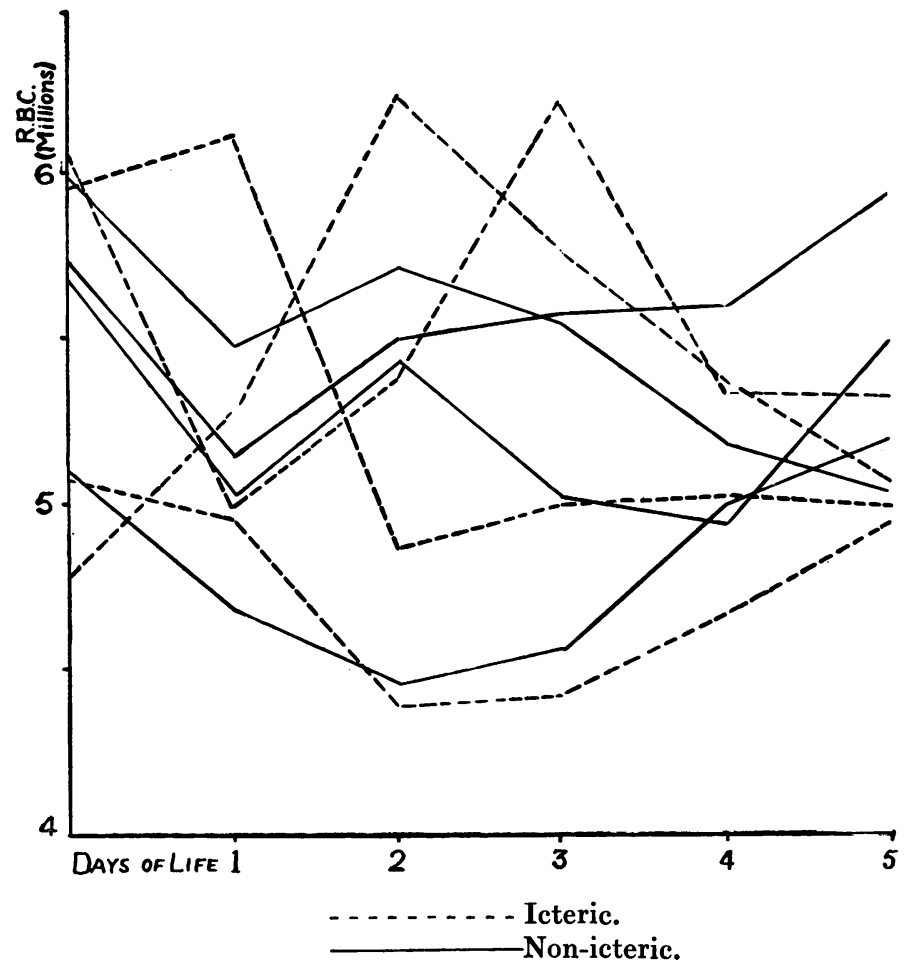

\begin{tabular}{|c|c|c|c|}
\hline & TOTAL RED CELLS (MILLIONS). & ICTERIC. & NON-ICTERIC. \\
\hline Birth & $5 \cdot 512$ & $5 \cdot 528$ & $5 \cdot 499$ \\
\hline lst day & $5 \cdot 160$ & $5 \cdot 446$ & $4 \cdot 996$ \\
\hline 'and, , & $5 \cdot 367$ & $5 \cdot 548$ & $5 \cdot 160$ \\
\hline 3rd ," & $5 \cdot 110$ & $5 \cdot 277$ & $4 \cdot 877$ \\
\hline 4 th , & $5 \cdot 176$ & $5 \cdot 234$ & $5 \cdot 080$ \\
\hline 5 th , & $5 \cdot 215$ & $5 \cdot 118$ & $5 \cdot 337$ \\
\hline
\end{tabular}

Average erythrocyte counts on first five days of life.

Discussion.

Andrewes concluded regarding bilirubin, the derivative of erythrocytes, that it was impossible to foretell from the amount of pigment whether jaundice would appear or not. It was similarly concluded from the present study of the erythrocytes themselves that it is impossible to predict from the erythrocyte count at birth whether an infant will develop icterus neonatorum or not. Erythrocyte counts during the first five days of life showed a higher average curve in infants developing 
icterus neonatorum and a slightly lower curve in infants not developing icterus, as compared with the average curve of all cases. But from individual infants' curves, nothing could be deduced. It is, therefore, believed that more than one factor exists in the production of icterus neonatorum, and it is submitted that the factors are:-(1) The degree of activity of erythrocyte production; and (2) the degree of activity of the reticulo-endothelial system, in short, a balance between erythrocyte production and destruction.

To maintain intra-uterine polycythaemia erythrocyte production must be active, as is borne out by the presence of nucleated red cells and polychromatophilic cells in smears from the newborn and after birth the production slows down to maintain a lower erythrocyte level.

Redundant erythrocytes are destroyed by the reticulo-endothelial system with consequent production of pre-hepatic bilirubin which, if produced in excess, causes jaundice. It is believed that this excess bilirubin production is an expression of reticulo-endothelial over-activity, either of itself or imposed upon it by over-production of erythrocytes.

In the present series of infants, those developing icterus neonatorum showed a higher average curve for erythrocytes during the first few days of life than the average of all cases, pointing to a persistence of intra-uterine activity which only died down gradually, and compensatory reticuloendothelial activity.

In view of the radical change from intra-uterine to extra-uterine conditions, it is not surprising that these systems overshoot the mark, one way or the other, before attaining physiological balance.

The apparent paradoxes of a low erythrocyte curve with icterus neonatorum, and a high erythrocyte curve without, are thus explained:-

\begin{tabular}{|c|c|c|}
\hline & ERYthrocyte production. & R-E. ACTIVITY. \\
\hline ICTERUS WITH LOW CURVE & $=$ NORMal OR UNDER-ACTIVE & + Over-active \\
\hline ICTERUS WITH HIGH CURVE & $=$ OVER-ACTIVE & + Over-ACtive \\
\hline NO ICTERUS WITH LOW CURVE & $=$ NORMAL OR UNDER-ACTIVE & + Normal \\
\hline No ICTERUS WITH High CURVE & $=$ OVER-ACTIVE OR NORMAL & + UNDER-ACTIVE \\
\hline
\end{tabular}

The fact that icterus neonatorum only occurs in some infants despite an initial polycythaemia in all, can thus be also explained. The transient nature of the jaundice, and the close proximity of average erythrocyte counts on the fifth day of life in both icteric and non-icteric infants, lends colour to the submission that icterus neonatorum is the result of trial and error between two physiological processes before they attain harmony.

\section{Cell counts at birth.}

Both the erythrocyte and white cell counts in an adult offer many possible sources of error, both technical and personal, in their estimation, 
but in a newborn infant is superadded both variation in the quality of blood from different sources $\left(\right.$ Drucker $\left.^{3}\right)$, and a variable stagnation of peripheral blood due to birth trauma and the radical change in the respiratory and circulatory systems at birth. Each investigator, setting his own standards can attain considerable accuracy in counts, but the comparison of different workers' results is impossible without the use of standard methods. For these reasons it is only possible to refer to an ' average' cell count at birth, as opposed to a ' normal' count at birth (see table below).

\section{ERYTHROCYTE VALUES AT BIRTH.}

\begin{tabular}{|c|c|c|c|}
\hline \multicolumn{4}{|c|}{ ERYTHROCYTES } \\
\hline & Year. & PER C.MYI. & \\
\hline AITKIN $^{9}$ & 1902 & $6,130,000$ & \\
\hline FeHrSON $^{10}$ & 1904 & $6,047,000$ & HaEMoglobin aVerage 110 Per cent. \\
\hline LuCAS ET AL ${ }^{14}$ & 1921 & $5,511,000$ & HaEMOGLOBin aVERAGe 117 PER CENT. \\
\hline MAYERS $^{16}$ & 1922 & $7,630,000$ & \\
\hline LIPPMAN $^{13}$ & 1924 & $5,200,000$ & \\
\hline $\mathrm{ZIBORDI}^{19}$ & 1925 & $6,380,000$ & HaEMOGLOBIN AVERAGE 114 PER CENT. \\
\hline FORKNER $^{11}$ & 1929 & $5,963,000$ & HaEMOgLobin aVerage 148.5 PER CENT. \\
\hline HAWKESLEY \& & 109 & $5,500,000$ & \\
\hline LiGHTWOOD $^{12}$ & & $6,000,000$ & \\
\hline WhitBy \& HYNES ${ }^{17}$ & 1935 & $7,000,000$ & HaEMOGLOBIN AVERAGE 151 PER CENT. \\
\hline
\end{tabular}

Mackay $^{15}$ tabulates the findings of, Appleton (1918), Hallez (1919), Hutchison (1904), Schiff (1890), and Williamson (1916). All investigators are agreed on a polycythaemia. In the present series of twenty cases the erythrocyte count at birth was found to be:-

$\begin{array}{lrrr} & \text { Average. } & \text { Maximum. } & \text { Minimum. } \\ \text { RED CELLS PER C.MM. } & 5,512,000 & 6,875,000 & 4,670,000 \\ \text { HaEMOGLOBIN, PER CENT. } & 118 & 140 & 102\end{array}$

The white cell and differential counts were made in fourteen of the cases, with the following results:-

TOTAL WHITE CELLS PER C.MM.

NEUTROPHIL POLYMORPHS

EOSINOPHIL POLYMORPHS

LYMPHOCYTES

LARGE MONONUCLEARS

NORMOBLASTS

Average.
13,350
$59 \cdot 8$
$2 \cdot 1$
$35 \cdot 6$
$2 \cdot 5$
$3 \cdot 5$

$\begin{array}{cc}\text { Maximum. } & \text { Minimum. } \\ 19,500 & 10,200 \\ 82 & 38 \cdot 5 \\ 4 \cdot 5 & 0 \\ 53 \cdot 5 & 2 \cdot 0 \\ 6 \cdot 0 & 0 \\ 14 & 0\end{array}$

Caesarean section.-Ten of the infants in the series were delivered by caesarean section at full term, for the following maternal reasons:-recent myomectomy 2 ; disproportion 6 ; myocardial degeneration 1 ; and ankylosis of left hip 1. The average red cell and haemoglobin values for ten caesarean-born infants are slightly, but definitely, lower than those of ten 
children born by natural means. This is probably due to the elimination of cyanosis and trauma associated with passage through the birth canal.

\begin{tabular}{|c|c|c|c|c|}
\hline & $\begin{array}{l}\text { CaEsarean. } \\
\text { Average. }\end{array}$ & $\begin{array}{l}\text { Caesarean. } \\
\text { Maximum. }\end{array}$ & $\begin{array}{l}\text { Caesarean. } \\
\text { Minimium. }\end{array}$ & $\begin{array}{c}\text { Natural birth. } \\
\text { Average. }\end{array}$ \\
\hline $\begin{array}{l}\text { RED BLOOI) CELLS, } \\
\text { NILLIONS PERR C. }\end{array}$ & $5 \cdot 381$ & 6.080 & 4.670 & $5 \cdot 633$ \\
\hline HALMOGLOBIN PER CENT. & 114 & 125 & 108 & 121 \\
\hline
\end{tabular}

Of the ten caesarean-born children, three developed icterus neonatorum -30 per cent. Of ten naturally-born children, six developed icterus neonatorum-60 per cent. These figures are not discussed because of the small number of cases.

\section{Conclusions.}

(1) The erythrocyte count at birth bears no relationship to development of icterus neonatorum.

(2) The average five-day erythrocyte curve of icteric infants is higher, and that of non-icteric infants lower than the average curve of all cases.

(3) No conclusion can be drawn from an individual five-day curve as to the occurrence of icterus neonatorum.

(4) Icterus neonatorum is an expression of temporary lack of balance between erythrocyte production and destruction.

(5) Average values are given for cell counts and haemoglobin estimations of newborn infants.

(6) Caesarean-born infants show a slightly lower average erythrocyte count and haemoglobin estimation than naturally-born infants.

We should like to thank especially Dr. J. R. Campbell Canney, Honorary Obstetrician to Addenbrooke's Hospital, and Dr. C. H. Whittle, Honorary Physician and Clinical Pathologist to Addenbrooke's Hospital, for kindly permitting and assisting us to carry out this investigation.

\section{REFERENCES.}

1. Andrewes, C. H., Quart. J. Med., Oxford, 1924-5, XVIII, 19.

2. Barcroft, J., Lancet, Lond., 1933, ii, 1021.

3. Drucker, P., Acta pediat., Uppsala, 1923, III, 1.

4. Goldbloom, A., \& Gottlieb, R., Am. J. Dis. Child., Chicago, 1929, XXXVIII, 57.

5. Goldbloom, A., \& Gottlieb, R., J. Clin. Investig., Lancaster, 1930, VIII, 375.

6. Goldbloom, A., \& Gottlieb, R., ibid, IX, 139.

7. Hirsch, A., Ztschr. f. Kinderh., Berlin, 1913, IX, 196.

8. Yllpo, A., ibid., 1913, IX, 208.

9. Aitkin, J., J. Obst. \& Gynaec. Brit. Emp., Lond., 1902, I, 414.

10. Fehrson, A. O. M., J. Physiol., Lond., 1904, XXX, 322. 
11. Forkner, C. E., Bull. Johns. Hopkins Hosp., Baltimore, 1929, XLV, 75.

12. Hawksley, J. C., \& Lightwood, R., Quart. J. Med., Oxford, 1934, III, 155.

13. Lippman, H. S., Am. J. Dis. Child., Chicago, 1924, XXVII, 473.

14. Lucas, W. P. et al, ibid, 1921, XXII, 525.

15. Mackay, H. M. M., Med. Res. Coun., Spec. Rep., No. 157, Lond., 1931.

16. Mayers, P., Arch. Int. Med., Chicago, 1922, XXX, 478.

17. Whitby, L. E. H., \& Hynes, M., J. Path. \& Bact., Lond., 1935, XL, 219.

18. Williamson, C. S., Arch. Int. Med., Chicago, 1916, XVIII, 505.

19. Zibordi, F., Ematologia Infantile, Milan, 1925. 